\title{
El clero y los usos políticos de la Virgen del Quinche en la sierra centro- norte de Ecuador (1883-1914)*
}

\begin{abstract}
Resumen
Este artículo analiza los usos políticos de la imagen de la Virgen del Quinche dentro de los cambios en la postura del clero sobre la relación Estado-Iglesia. Se estudia, mediante manuscritos e impresos, el discurso del clero sobre esa Virgen, y las prácticas que este fomentó, ajustó y fortaleció conforme el contexto y el cambio en su postura lo requirieron. El estudio se limita a la región Sierra centro-norte de Ecuador, un espacio que concentraba a la mayoría del clero ecuatoriano. Como resultado se identificaron dos momentos en la posición del clero y los usos políticos de la imagen: En el primero, uno intransigente, la Virgen fue estandarte de la oposición a la separación de EstadoIglesia mediante libros, visitas a la Capital y romerías. Después, frente a reformas de corte liberal, el clero apoyó la independencia de la Iglesia e incentivó prácticas devotas como peregrinaciones hacia el santuario.
\end{abstract}

\section{Palabras clave}

Tesauro: Iglesia, catolicismo, política, clero.

Autor: siglo XIX.

Referencia para citar este artículo: Vizuete Marcillo, Luis Esteban. "El clero y los usos políticos de la Virgen del Quinche en la sierra centro-norte de Ecuador, 1883-1914". Anuario de Historia Regional y de las Fronteras 23.2 (2018): 85-113.

Fecha de recepción: 17/09/2017

Fecha de aceptación: 05/03/2018

Luis Esteban Vizuete Marcillo: doctorante en Historia de El Colegio de México, México. Historiador de la Pontificia Universidad Católica del Ecuador, Ecuador. Miembro correspondiente de la Academia Ecuatoriana de Historia Eclesiástica, Ecuador. Código ORCID: https://orcid.org/0000-0001-5867-6335. Correo electrónico: lvizuete507@puce.edu.ec.

\footnotetext{
*El artículo forma parte del proyecto " Clamando á mi Madres del Quinche’: usos de la imagen de la Virgen del Quinche en la arquidiócesis de Quito entre 1895 y 1910”, el cual se complementó con una investigación sobre la misma imagen entre 1883 y 1895 . Fue realizado bajo el amparo institucional de la Pontificia Universidad Católica del Ecuador y la Academia Ecuatoriana de Historia Eclesiástica.
} 


\title{
Clergy and the Political Uses of the Cult to Our Lady of El Quinche at the Central- Northern Highland in Ecuador, 1883-1914
}

\begin{abstract}
This article analyzes the political uses of Our Lady of Quinche's image within the changes in the position of the clergy on the relationship State-Church. Thus, manuscripts and printed sources have been used to analyze the clergy's discourse about this Virgin's denomination and the practices that it encouraged, adjusted and strengthened around her cult according to the context and posture changes in the clergy's position. This study is focused on the Central-Northern Highlands of Ecuador, an area which concentrated the majority of the Ecuadorian's Clergy. As a result, there were two moments in the clergy's position and the political uses of the Virgin's cult. Firstly, an intransigent one, where the Virgin was banner of opposition to the separation of State-Church through books, visits to the Capital and pilgrimages. Then, a second instance, when faced with some liberal reforms, clergy supported church independence from state and encouraged devoted practices such as pilgrimages to the Quinche Sanctuary.
\end{abstract}

Keywords

Thesaurus: Church, Catholicism, Politics, Clergy.

Author's keywords: 19th Century.

\section{O clero e os usos políticos da Virgem de Quinche na serra centro-norte do Equador, 1883-1914}

\section{Resumo}

Este artigo analisa os usos políticos da imagem da Virgem de Quinche dentro das mudanças na postura do clero sobre a relação Estado-Igreja. Para isso se analisa, mediante manuscritos e documentos impressos, o discurso do clero sobre essa Virgem e as práticas que este fomentou, ajustou e fortaleceu conforme o contexto e a mudança em sua postura o requereram. O estudo se limita à região da Serra centro-norte do Equador, um espaço que concentrava a maioria do clero equatoriano. Como resultado se identificaram dois momentos na postura do clero e os usos políticos da imagem. No primeiro, um intransigente, onde a Virgem foi estandarte da oposição à separação entre o Estado e a Igreja mediante livros, visitas a Capital e romarias. Depois, frente às reformas de corte liberal, o clero apoiou a independência da Igreja e incentivou práticas devotas como peregrinações até o santuário.

Palavras-chave

Thesaurus: Igreja, catolicismo, politica, clero.

Palavras-chave do autor: século XIX. 


\section{Introducción}

El siglo XIX es crucial para entender la Iglesia tal como la concebimos el día de hoy. Roberto Di Stefano sostiene que esta sufrió un proceso de reacomodo y reconfiguración, a lo largo de ese siglo, respecto de la lógica corporativa que esta tuvo durante el Antiguo Régimen. ${ }^{1}$ Así, tanto las instituciones eclesiásticas, las prácticas religiosas y las relaciones entre los sectores eclesiales ${ }^{2}$ se modificaron dentro de un contexto republicano. El mismo concepto Iglesia adquirió diferentes concepciones: comunidad de fieles, potestad eclesiástica y entidad equiparable al Estado. ${ }^{3}$

Ese mismo siglo fue importante para el reforzamiento y readaptación del marianismo a lo largo del orbe católico. La imagen de la Virgen experimentó un doble movimiento dentro de lo que se han denominado las guerras culturales que enfrentaron al clero, seglares y laicos católicos con sus gobiernos, el Estado y otros sectores sociales. ${ }^{4}$ Por un lado, los usos de las imágenes y la difusión de sus cultos necesitaron de la prensa, la movilización de masas católicas y la creación de nuevas asociaciones. Por el otro, esos tres aspectos dependieron del marianismo para ganar público y adeptos a la causa católica.

En 1854, como resultado de un largo proceso, Pío IX declaró el dogma de la Inmaculada Concepción. Cuatro años después, en Francia, la aparición de la Virgen de Lourdes marcó un hito en la historia de la Iglesia. Este evento, junto a otros del mismo tipo a lo largo de Europa, se convirtió en un referente. De ese modo, Roma y las órdenes religiosas francesas difundieron el modelo devocional francés basado en el reforzamiento del vínculo entre los devotos y el objeto de culto, y la identificación de la modernidad como responsable del contexto que afrontaba la Iglesia, frente a lo cual la única forma de alcanzar la redención era la conversión. ${ }^{5}$ Por un lado, la Santa Sede vinculó el milagro de Lourdes con el dogma de la Inmaculada y la idea de un mundo en decadencia. Por el otro, la llegada a América de las órdenes modernas, fundadas en Francia, facilitó la dispersión del modelo. ${ }^{6}$ México, ${ }^{7}$ España, ${ }^{8}$ Ecuador y otros países hispanoamericanos buscaron implementar dicho modelo a los cultos locales.

\footnotetext{
${ }^{1}$ Roberto Di Stefano, "Catolicismo, secularización y laicidad en América Latina”, Religión y Politica en América Latina (Ponencia III Congreso Latinoamericano y Caribeño de Ciencias Sociales, FLACSO, Quito, 2015); Roberto Di Stefano, “¿De qué hablamos cuando decimos 'Iglesia’? Reflexiones sobre el uso historiográfico de un término polisémico", Ariadna histórica. Lenguajes, conceptos, metáforas 1 (2012): 197-220.

${ }^{2}$ Entiendo por eclesial a una comunidad de creyentes en la que se incluyen tanto el clero como los fieles. Véase: Ana María Bidegain, "De la historia eclesiástica la historia de las religiones", Historia crítica 12 (1996): 5-16.

${ }^{3}$ Stefano, “¿De qué hablamos cuando decimos 'Iglesia'?” 221.

${ }^{4}$ Christopher Clark, "The New Catholicism and the European culture wars", The European culture wars, ed. Christopher Clark y Wolfram Kaiser (New York: Cambridge University press, 2003) 11-46.

${ }^{5}$ José Alberto Moreno, Devociones políticas: cultura católica y politización en la Arquidiócesis de México, 1880-1920 (México: Colegio de México, 2013) 40.

${ }^{6}$ Moreno 50-55.

${ }^{7}$ Moreno 55-62.

${ }^{8}$ Francisco Ramón, La Virgen del Pilar dice... Usos Políticos y nacionales de un culto mariano (Zaragoza: Universidad de Zaragoza, 2014).
} 
Antes de introducir el caso ecuatoriano es preciso aclarar que el dominio eclesiástico y la religiosidad no son lo mismo. ${ }^{9}$ El cambio hacia un contexto republicano implicó que el clero reajuste la forma en la cual se relacionaba con la feligresía, intervenía en las prácticas religiosas e interpelaba a las conciencias de los feligreses. En ese sentido, a lo largo del siglo XIX y a principios del XX, los usos políticos que el clero hizo de una imagen no se relacionan solo a las formas en las cuales ésta fue empleada, sino a los discursos que se construyeron alrededor de esta, las prácticas en las que estaba inserta y el interés de ese mismo clero por fortalecer sus lazos con otros sectores eclesiales, convencer a los fieles o incentivar su participación en defensa de la Iglesia. Cultos como el de la Virgen de Guadalupe en México, la de Luján en Argentina, el Pilar en España o el Quinche en Ecuador experimentaron un modelo devocional híbrido en el cual se recurrió al modelo francés, pero con la particularidad de que todas esas advocaciones ya contaban con algunos siglos de existencia, una feligresía y una fama heredada de la época colonial. ${ }^{10}$

Pocas imágenes marianas lograron convertirse en una advocación nacional como la Virgen de Guadalupe. Esta, a lo largo del XIX fue asociada con la necesidad de salvar a México del liberalismo, permitió la crítica a las reformas liberales, expresó el camino de martirio que había seguido México debido a las doctrinas modernas y, sobre todo, representó la garantía del pacto que unía la nación mexicana con Dios. ${ }^{11}$ Otros casos, como el de España, experimentaron prácticas similares a las de Lourdes, sin embargo, las lógicas regionales no permitieron que el proyecto de un culto nacional se concretara. ${ }^{12}$ Para el caso ecuatoriano y argentino, si bien sus áreas de influencias fueron regionales, los cultos a la Virgen del Quinche y a la Virgen de Luján adquirieron alcances nacionales solo desde mediados del siglo XX. Aunque esto no quiere decir que el clero no les dio especial atención. De hecho, la historia de la Virgen de Luján y la construcción de su basílica sucedieron durante los años de conflicto entre el clero y el gobierno liberal. ${ }^{13}$

Entre 1883 y 1914, el clero ecuatoriano buscó reconectarse, dentro de los vínculos republicanos, con la feligresía. Por lo tanto, en este artículo se analiza los usos políticos que hizo el clero de la imagen de la Virgen del Quinche, con especial atención en el paso de una postura intransigente ${ }^{14}$ que defendía una República católica

\footnotetext{
${ }^{9}$ Brian Connaugton, “La nueva historia política y la religiosidad: ¿Un anacronismo en la transición?”, Entre la voz de Dios y el llamado de la patria (México: Fondo de Cultura Económica, Universidad Autónoma Metropolitana, 2010) 59-83.

${ }^{10}$ Moreno 128-138.

${ }^{11}$ Moreno 132.

${ }^{12}$ Moreno 53.

${ }^{13}$ Para ahondar en el conflicto Estado-Iglesia en Argentina, véase: Michael Burdick, For God and the Fatherland. Religion and politics in Argentina (New York: The State University of New York Press, 1995) 17-44.

${ }^{14}$ Manuel Ceballos Ramírez define a los intransigentes como una postura dentro de la Iglesia católica decimonónica que "[...] condenaron indistintamente a lo largo del siglo todas las corrientes que de algún modo evadían, atacaban o ignoraban a la Iglesia: liberalismo, racionalismo, positivismo, etc. Es más, la propuesta intransigente partía del supuesto de la creación de una nueva cristiandad, opuesta y
} 
y se oponía a la separación entre Estado-Iglesia hacia una postura en la que se buscaba la independencia de la Iglesia frente al Estado. Se ha escogido la región sierra centronorte del Ecuador, conformada por las diócesis de Ibarra, Quito y Riobamba debido a que éstas concentraban la mayor cantidad de miembros del clero del país. ${ }^{15}$

A lo largo del siglo XIX, la Iglesia en Ecuador reacomodó y reconfiguró ${ }^{16}$ las relaciones con sus miembros, el poder central y la curia romana. Desde la segunda mitad del siglo XIX, el gobierno del presidente Gabriel García Moreno (1861-1865; 18691875) reforzó la unión Estado-Iglesia al entregar la educación, la beneficencia y otros espacios a congregaciones religiosas de fundación moderna traídas de Europa, a un clero regular reformado ${ }^{17} \mathrm{y}$ a uno secular más ilustrado. Este proyecto no solo buscaba poner en consonancia las instituciones estatales con la Religión, sino que promovían una reforma moral ${ }^{18}$ y la formación de una generación de clérigos convencidos y defensores de una "República consagrada al del Sagrado Corazón" ${ }^{19}$ El clero tenía el poder de censurar, la injerencia en los temas de enseñanza, el control sobre la educación básica, secundaria y artesanal, entre otras prerrogativas.

Entre 1883 y 1914 los cambios en la postura del clero frente a la relación Estado-Iglesia presentan dos momentos. El primero comprendido entre 1883-1905 y un segundo momento entre 1905-1914. En el gobierno indicado de García Moreno (garcianismo), la Iglesia quedó supeditada al Estado como garante de su funcionamiento. Sin embargo, a partir de 1876, el accionar político de los liberales puso en jaque a dicho modelo político, después de la muerte de García Moreno, y colocó en el poder a Ignacio de Veintimilla (1876-1883) quien, después de empezar con un programa radical, no demoró en desencantar a los mismos liberales, a los conservadores y a la Iglesia.

A finales de 1882, en la Sierra, estalló una guerra civil identificada con afanes restauradores frente al autoritarismo y políticas liberales del presidente Ignacio de Veintimilla. Si bien con dichos acontecimientos varios conservadores y gran parte del

paralela a la sociedad secular. Primero por medio de la lucha franca [...] [y] a través de la recuperación de algunos espacios de la sociedad y finalmente por la recuperación del espacio político [...] proponían la revitalización de la llamada civilización católica". Manuel Ceballos Ramírez, El catolicismo social: un tercero en discordia (México: Colegio de México, 1991) 23-24.

${ }^{15}$ Solo la provincia de Pichincha, centro de la Arquidiócesis de Quito, concentraba a cerca del 50\% del clero regular de Ecuador. Casi lo mismo sucedía con el clero secular para toda la Arquidiócesis. José Félix Valdivieso, "Nóminas de los miembros del clero regular", Quito, 1908. Archivo Nacional del Ecuador, Quito, Ministerio del Interior, Pichincha, Caja 105; "Crónica con datos estadísticos sobre el clero", El Comercio, (Quito) 23 de diciembre de 1909; Enrique Ayala Mora, Historia de la revolución liberal ecuatoriana (Quito: Corporación Editora Nacional, 2002) 208.

${ }^{16}$ Este fenómeno es más amplio y engloba a toda América Latina: Stefano, "Catolicismo, secularización y laicidad en América Latina”.

${ }^{17}$ Ana Buriano, Navegando en la borrasca. Construir la nación de la fe en el mundo de la impiedad, Ecuador, 1860-1875 (México: Instituto Mora, 2008) 239-251.

${ }_{18}$ Juan Maiguashca, "El proceso de integración nacional en el Ecuador: el rol del poder central, 18301895", Historia y Región en el Ecuador, ed. Juan Maiguashca (Quito: FLACSO, York University, IFEA, 1994): 355-424.

${ }^{19}$ Fernando Hidalgo, La República del Sagrado Corazón (Quito: Corporación Editora Nacional, UASB, 2013). 
clero deseaban retornar al modelo de la República católica, los gobiernos progresistas $(1884-1895)^{20}$ que asumieron el poder se distanciaron del programa garciano al establecer gobiernos católicos que pregonaban la supremacía de la ley ${ }^{21}$ y querían implementar reformas cercanas a la idea de León XIII de que el clero no debía incursionar en política. La Iglesia, sin embargo, mantuvo gran injerencia sobre las políticas de los gobiernos progresistas y no enfrentó más que algunos intentos de reforma puntuales como la sustitución del diezmo o la prohibición de que el clero participase en política.

La mayor cantidad de reformas en materia de negocios eclesiásticos se dieron entre 1895 y 1905 . En 1895 estalló lo que la historiografía denominó "Revolución liberal". En el contexto de estallido de esta, fueron importantes el gran conflicto entre facciones políticas, los intereses económicos de algunos sectores agroexportadores de la costa (litoral) y otros hacendatarios de la Sierra. Los levantamientos empezaron como reacción a la crisis política, resultado de la polémica internacional en la cual Ecuador había prestado su bandera para la venta de un buque de guerra. Desde las ciudades de la costa, lideradas por militares y políticos liberales, las tropas revolucionarias (montoneras) avanzaron a otras provincias de Ecuador. Las montoneras contaron con el apoyo de otros sectores liberales del interior de Ecuador. Estos grupos lograron tomar la ciudad de Quito y con ello el control de casi la totalidad del país.

A partir del triunfo de Eloy Alfaro y sus aliados, estos realizaron una serie de reformas que afectaban el orden que había defendido el clero desde el garcianismo. La Iglesia, durante casi diez años, se resistió a una posible separación de poderes y más aún a abandonar la tutela directa del Estado. Los liberales, si bien no sin negociar, intentaron contrarrestar el poder social de la Iglesia, buscaron regularla asumiendo competencias más directas en educación y registro civil, entre otras. En 1897, a pesar de la gran oposición del clero y de los sectores conservadores, los liberales dictaron una Constitución con reformas moderadas. Asimismo, entre los últimos años del siglo XIX y los primeros del XX, los liberales intentaron introducir reformas laicistas en educación pública (1905), ${ }^{22}$ matrimonio civil (1902) o mediante un patronato de facto $^{23}$ que le otorgaba al Ejecutivo la capacidad de escoger a los candidatos a obispos (1899). A esta última reforma la Iglesia logró hacerle frente recurriendo a la desobediencia o apelando a su influencia social y económica. ${ }^{24}$ Sin embargo, el monopolio del que gozó por décadas se vio fuertemente afectado.

\footnotetext{
${ }^{20}$ Gobiernos influenciados por el liberalismo católico.

${ }^{21}$ Maiguashca 355-424.

${ }^{22}$ El análisis sobre este tema ha sido trabajado por Katerinne Polanco, La agenda educativa en el periodo liberal-radical 1895-1912 (Quito: Universidad Andina Simón Bolívar, 2015).

${ }^{23}$ Roberto Blancarte explica que, en algunas ocasiones, los gobiernos liberales aprobaron en sus cámaras un Patronato suscrito por ellos sin la aceptación de la Santa Sede para poder controlar de manera más efectiva a la Iglesia. Véase: Roberto Blancarte, "Laicidad y laicismo en América Latina”, Estudios Sociológicos 26 (2008): 139-164.

${ }^{24}$ Para el caso de la educación véase: Emmanuelle Sinardet, "El papel de los padres de familia: táctica de la Iglesia en la Lucha contra las reformas educativas liberales en Ecuador (1906-1914)", Familia y educación en Iberoamérica, coord. Pilar Gonzalbo (México: Colegio de México, 1999) 213-222.
} 
Las reformas liberales no fueron el único aspecto al que debió hacer frente el clero en Ecuador. Hasta 1905, casi todas las diócesis serranas y costeñas habían quedado vacantes. ${ }^{25}$ Éstas debieron manejarse por medio de administradores apostólicos y vicarios, los cuales no tenían las mismas facultades que los obispos. El gobierno liberal se había rehusado a aceptar nuevas provisiones de prelados debido a la Ley de Patronato que proclamó el gobierno en $1899 .{ }^{26}$ Por lo cual, el obispo de Ibarra, Federico González Suárez (1895-1906) fue el último prelado, designado por el Concordato y la Santa Sede, que estuvo en funciones entre 1905 y 1907. En 1906, la Santa Sede lo designó como nuevo arzobispo de Quito. Sin embargo, el gobierno liberal se resistió a reconocer su nombramiento, aunque no impidió el ejercicio de sus labores pastorales. ${ }^{27}$

En un segundo momento, la Iglesia y el Estado tuvieron que ceder. Tanto el uno como el otro sufrieron cambios dentro del conflicto. A partir de la Constitución de 1906 ambas partes dieron pasos para diferenciar las esferas seculares y religiosas. La nueva Constitución separó formalmente Estado e Iglesia, frente a lo cual, el clero, dirigido por Federico González Suárez, argumentó que el Patronato ya no tenía vigencia y que el gobierno no podía intervenir ni frenar la provisión de obispos para las diócesis vacantes. ${ }^{28}$

En el caso de la Iglesia, la sujeción entre ambas entidades había dado muestras de no convenirle mucho, así que optó por proponer su independencia frente al Estado. Esto requería una relación más cercana con la sociedad civil con el fin de interpelarlo por medio de ésta. La iniciativa no solo implicó reformas dentro de la Iglesia, también requirió adherirse con mayor fuerza a un proceso de "recristianización" 29 que se manejaba desde Roma y que involucraba un mayor énfasis en la labor pastoral y las prácticas devotas.

Para 1906, el liderazgo del caudillo liberal Eloy Alfaro (1895-1901; 1906-1910) se había desgastado. En 1906, éste dio un golpe de estado contra el presidente liberal

\footnotetext{
${ }^{25}$ En 1900 murió el obispo de Cuenca, Miguel León; en 1902 los obispos de Portoviejo, Pedro Schumacher, y de Loja, José María Masiá; en 1904 falleció el arzobispo de Quito, Pedro Rafael González y Calisto, y en 1905 el obispo de Riobamba Arsenio Andrade.

${ }^{26}$ Santiago Castillo, La Iglesia y la Revolución Liberal (Quito: Banco Central del Ecuador, 1995).

${ }^{27}$ Los usos políticos de la Virgen del Quinche no fueron iniciativa de un solo obispo o sacerdote, algunas generaciones de estos participaron en ese proceso. Por esa razón, en ocasiones se dará el nombre de los prelados que fueron arzobispos de Quito u obispos de Ibarra. Es preciso aclarar que, a fines del siglo XIX y principios del XX, algunos de los obispos de Ibarra fueron nombrados, después, arzobispos de Quito, asunto que puede resultarle confuso al lector. En cuanto a los obispos de Ibarra, entre 1876 y 1893 , Pedro Rafael González y Calisto estuvo a cargo de esa diócesis. Dos años después, Federico González Suárez fue nombrado obispo en su reemplazo hasta 1906. Por otra parte, entre 1882 y 1893, Ignacio Ordóñez fue el arzobispo de Quito, una vez muerto este, Pedro Rafael González y Calisto fue nombrado su sucesor hasta 1904, año en el que murió. Entre 1904 y 1906 la arquidiócesis de Quito quedó vacante hasta que se proveyó a Federico González Suárez como arzobispo de esta.

${ }^{28}$ Amalio Puga, La ley y el Ilmo. Federico González Suárez (Quito: Imprenta Nacional, 1908).

${ }^{29}$ Margaret Anderson, "Las huestes papales: el resurgimiento católico y la transición europea hacia la democracia", Historia y Sociedad 6 (1999): 38-67. El término recristianizar se toma de estudios sobre el tema y de las referencias hechas por los mismos actores.
} 
Lizardo García, a tan solo seis meses de su posesión. El alfarismo fue catalogado de autoritario y algunos de sus aliados se distanciaron. Sin embargo, el conflicto llegó a su máximo punto el 25 de abril de 1907, cuando un grupo de jóvenes, miembros del Club Electoral Universitario, fueron perseguidos y algunos de ellos asesinados por elementos del ejército. El grupo se manifestó en contra de una tiranía y exigió el correcto curso de las elecciones legislativas que se aproximaban. Su protesta logró convocar a la prensa no oficial, los artesanos y otros grupos. Empero, el gobierno calificó a dicha manifestación como un motín. El descontento social llegó al punto que profesores de las universidades, ministros del poder judicial y otros empleados renunciaron a sus cargos en rechazo a lo sucedido. Del mismo modo, antiguos aliados de Alfaro lo cuestionaron abiertamente aconsejando su renuncia. ${ }^{30}$ En ese contexto, el liberalismo se fragmentó entre los constitucionalistas que defendían la vía electoral y los alfaristas que confiaban en la imagen de su caudillo. ${ }^{31}$

Ese año, el arzobispo González Suárez empezó a negociar con la Santa Sede el nombramiento de obispos. En mayo de 1907 envió al canónigo Manuel María Pólit a Roma con ese fin, logrando el nombramiento de obispos para las diócesis serranas. Para el año siguiente, los nuevos prelados ya habían sido preconizados. La nueva Constitución y el quiebre del liberalismo generaron un contexto favorable para el fortalecimiento de la jerarquía eclesiástica ecuatoriana. Durante el resto de su administración pastoral, Federico González Suárez se preocupó por fomentar la independencia de la Iglesia frente al Estado ${ }^{32}$ y, como él mismo refirió, la reconstrucción de la Provincia Eclesiástica Ecuatoriana. ${ }^{33}$ Los usos políticos de la Virgen del Quinche permiten apreciar el paso de una postura intransigente a otra como la que se acaba de describir.

\section{El fortalecimiento de los lazos entre el clero y los fieles: los usos de la imagen de la Virgen del Quinche y la construcción de una mariología local (1883-1905)}

Como se mencionó antes, entre 1883 y 1895, la Iglesia consolidó la idea de Ecuador como una República católica, legada por el garcianismo. ${ }^{34}$ Esto implicaba que el Estado estaba obligado a cuidar del culto y la Iglesia. Si bien existía un Concordato

\footnotetext{
${ }^{30}$ Luis Robalino Dávila, Orígenes del Ecuador hoy. El ocaso del Viejo luchador, t. 8 (Puebla: Cajica, 1969) 258-303.

${ }^{31}$ Ana María Goetschel, “Las paradojas del liberalismo y las mujeres: coyuntura 1907-1909”, Celebraciones centenarias y negociaciones por la nación ecuatoriana, ed. Valeria Coronel y Mercedes Prieto (Quito: FLACSO, 2010), 209-240.

${ }^{32}$ La idea de independencia del clero no fue una idea exclusiva de González Suárez. Antes de ser nombrado obispo, otros miembros del clero, como el Vicario Capitular de Quito, Ulpiano Pérez, ya habían apuntado que era necesaria. Véase: Ulpiano Pérez, "Carta del Vicario Capitular al Delegado Apostólico, Alejandro Bavona, pidiendo normas de conducta”, Quito, 1904, Archivo Arzobispal de Quito, Quito, Secretaría de Gobierno, Caja 14, Libro copiador de notas dirigidas al Delegado Apostólico.

${ }^{33}$ Federico González Suárez, "Carta de Federico González Suárez a Andrés Machado", Quito, 16 de abril de 1910. Archivo Arquidiocesano de Quito, Quito, Secretaría de Gobierno, Caja 14.

${ }^{34}$ Julio María Matovelle, "Nuestro Propósito", República del Sagrado Corazón de Jesús 1.1 (1884): 1-6.
} 
que regulaba las relaciones entre las dos potestades, la Iglesia era capaz de interpelar directamente al gobierno central amparada en su "gran influencia" en la sociedad y en las obligaciones que la Constitución establecía:

Las elecciones, ¿serán asunto de política? ¡Indudablemente! Las elecciones, ¿nada tendrán que ver con la moral?... La convención futura debe dictar la constitución de la República y las demás leyes secundarias: ha de determinar la manera como se deben invertir los caudales públicos: ha de elegir al primer magistrado de la nación, á los ministros de justicia y á otros muchos funcionarios públicos, como jueces del tribunal de cuentas, consejeros de estado \&.\&...ya veis, pues, que en manos de una asamblea constituyente se pone honra nacional, moral pública, justicia, educación de la juventud, garantías de la propiedad y, sobre todo, y ante todo, la Religión, que es el bien mayor del que pueden gozar los pueblos. ${ }^{35}$

Dentro de ese marco se podrán comprender los "usos políticos" que hizo el clero de la imagen de la Virgen del Quinche. Este caso permite una aproximación hacia las iniciativas clericales de oposición al liberalismo, y de fortalecimiento de los lazos con la feligresía. El discurso sobre la Virgen como un remedio a los males políticos marcó los itinerarios que siguieron los actores eclesiales. Hay cuatro puntos cruciales a tomar en cuenta para entender este proceso: el planteamiento de una mariología local sobre la Virgen del Quinche, el impulso de las visitas de la Imagen, el incentivo de romerías, y el manejo de la prensa.

El culto a la Virgen del Quinche data de fines del siglo XVI, cuando un grupo de indígenas del anejo de Oyacachi, en las estribaciones de la cordillera de los Andes que dan hacia la Amazonía, compró del escultor Diego de Robles una imagen de la Virgen. La imagen pasó algunos años en esa localidad hasta que, tras una acusación al gobernador de indios de haber colocado a la imagen sobre una cabeza de oso para celebrar una fiesta, ésta fue llevada por orden del obispo de Quito -en 1604- al pueblo del Quinche, localidad a 60 kilómetros al nororiente de la ciudad de Quito.

El fortalecimiento del culto a la Virgen del Quinche, y su relación con un discurso antiliberal, fue impulsado entre 1883 y 1905 por un grupo de intelectuales del clero y las autoridades eclesiásticas. Los presbíteros Carlos Sono, Abel García, Manuel María Pólit y Julio María Matovelle escribieron crónicas sobre las prácticas religiosas alrededor de la imagen, su historia e incentivaron una serie de peregrinaciones desde Quito hacia la parroquia del Quinche. El apoyo del arzobispo de Quito Ignacio Ordóñez (1882-1893) y el obispo de Ibarra, Pedro Rafael González y Calisto (18761893) les permitió obtener los permisos para movilizar la imagen a lo largo de la Arquidiócesis de Quito, y a los principales centros poblados de las diócesis vecinas de Ibarra y Riobamba. Estos obispos también fueron quienes dispusieron que la imagen sea trasladada del Quinche hacia Quito. Una vez allí, los canónigos, párrocos y rectores de los distintos templos apoyaban en la organización del culto. El papel de la prensa también fue crucial, periódicos como La República del Sagrado Corazón de Jesús, dirigido por Matovelle, El Industrial, redactado por Julián de San-Martín

${ }^{35}$ Ignacio Ordóñez, Circular a los venerables párrocos de la Arquidiócesis (Quito: Imprenta del Clero, 1883) 2. 
(artesano-industrial) y El Boletín Eclesiástico dirigido por el canónigo Ulpiano Pérez hicieron un seguimiento del culto a la Virgen y las visitas que hacía la imagen. Es preciso acotar que entre 1883 y 1897, los párrocos del Quinche, Juan Bautista Vaca y Abel Araujo se limitaron a seguir las disposiciones que dictaban los obispos, distinto a sus sucesores que años después, bajo el argumento de proteger el culto a la Virgen, discreparon sobre las disposiciones de González Suárez, en 1910, y negociaron un punto medio entre la curia y los fieles. ${ }^{36}$

\subsection{Una mariología local}

En América Latina la década de 1880 fue importante en cuanto a la producción de trabajos sobre las diferentes devociones de la Virgen. En México y Argentina, las de Guadalupe y Luján no solo contaron con las primeras iniciativas para sus santuarios, sino también con los primeros escritos sobre las historias de las respectivas imágenes. ${ }^{37}$ Esto no fue un caso aislado de Latinoamérica, sino que respondía a una lógica en la cual la curia romana impulsó los cultos marianos, especialmente después de la encíclica Ineffabilis Deus (1854), en la cual el Papa no solo intentó mostrar su poder pastoral sobre la Iglesia, sino que también resolvió el polémico dogma de la Inmaculada Concepción.

Los cultos marianos fueron parte del proyecto de reforma de la Iglesia con el fin de recuperar o defender los espacios que se vieron amenazados frente al liberalismo y a los Estados modernos. ${ }^{38}$ Dentro de esto, una mariología refiere una serie de discursos oficiales producidos sobre la Virgen, los cuales fueron traducidos o matizados en prácticas religiosas. ${ }^{39}$ Para el caso de la Virgen del Quinche, el clero de la región centro-norte estructuró una historia sobre la Imagen, una visualidad y continuó refrescando el material producido.

El planteamiento de una mariología local para la Virgen del Quinche no solo respondía a la emulación de lo que Roma había hecho con una mariología general, sino que estaba basada en la intención de resignificar un culto colonial de amplia acogida con intereses republicanos de tinte antiliberal. Esto no quiere decir que se marcó una ruptura con la tradición de casi trescientos años con la que contaba la Virgen, más bien

\footnotetext{
${ }^{36}$ Juan Bautista Vaca, "Pedido de regreso de la Virgen", Quinche, 20 de septiembre de 1883. Archivo Arquidiocesano de Quito, Quito, Parroquias, El Quinche, Caja 59; Abel Araujo, "Carta del Vicario Foráneo del Quinche al arzobispo sobre ayuda de los jesuitas en la fiesta de la Virgen”, Quinche, 9 de noviembre de 1897. Archivo Arquidiocesano de Quito, Quito, Nueva Sección, Caja 14.

${ }^{37}$ Patricia Fogelman, "Dos exvotos contra el Estado liberal: la Basílica y el libro de Salvaire sobre la historia del culto de Luján", El culto mariano en Luján y San Nicolás, eds. Patricia Fogelman, Mariela Ceva, y Claudia Touris (Buenos Aires: Biblos, 2013) 25-49; David Brading, Virgen de Guadalupe (México: Taurus, 2002).

${ }^{38}$ Adriana Bautista, "La coronación pontificia de las imágenes marianas de México y la afirmación en la soberanía social de la Iglesia católica durante el porfiriato", Diálogos con una trayectoria intelectual: Marcelo Carmagnani en El Colegio de México, ed. Yovana Celaya (México: Colegio de México, 2014) 347-483.

${ }^{39}$ Claude Langlois, "Conférence de M. Claude Langlois", Écloe practique des hautes études, section des sciences religieuses. Annuaire 104 (1995): 481-490.
} 
acogía las continuidades coloniales y las contextualizaba en el marco republicano dentro de lo que Lomné explica como la identificación de la Virgen como imagen de la República. ${ }^{40}$

En 1883, el sacerdote Carlos Sono escribió una historia de la Virgen del Quinche en la que realzaba su potencial taumatúrgico y de remedio frente a las calamidades públicas. En general, Nuestra Señora del Quinche ${ }^{41}$ contaba con material de archivo y la oralidad de los pobladores del pueblo del Quinche en una narración sobre la historia de la imagen en cuatro actos: génesis, éxodo, desarrollo de la ecclesia y el fin. La historia empezaba con la llegada de la Virgen y sus primeros milagros en Oyacachi, continuaba con su traslado hacia el Quinche y los casi tres siglos de portentos realizados. La teleología del relato lo conducía hacia un presente escatológico en el cual la Iglesia debía enfrentarse al liberalismo, evolucionismo, entre otros, con el fin de conservar el Reino de Dios. De ese modo, el clero planteaba que la Virgen era aquel ser enviado para proteger a los fieles:

[El alma del impío como] una tendencia orgánica que le lleva á la satisfacción de instintos que le son comunes con los irracionales y cuya satisfacción constituye su fin único; su origen no se levanta es verdad, al mismo Dios, á ser hechura inmediata de sus manos, criado rey de la naturaleza, superior á todo lo visible, con un alma imagen de la augusta Trinidad, pero en cambio lo remonta aun mucho más alto, como las aguas del Nilo que van á ocultar sus primeros manantiales en las desconocidas soledades del África, aquel va á encontrar sus primeros progenitores en sus espesos bosques y á descubrir en el Orangután su primer ascendiente. Así se burla Dios de los impíos, entregándolos á las inepcias de su razón, y á los instintos depravados de sus pasiones! Sí, frente á frente del siglo más descreído y racionalista, en medio de una nación que, proclamando, no se sabe qué filosofía, arrastra su inteligencia por el fango del más inmundo materialismo. ${ }^{42}$

Carlos Sono veía en Lourdes el testimonio de un culto masivo que mostraba las gracias divinas a través de la Virgen, el caso más emblemático de una serie de prodigios que habían sucedido en Europa. Sono, por medio de su narrativa, reinsertaba los milagros coloniales de la Virgen del Quinche al contexto del siglo XIX. La obra del presbítero no solo fue el punto de partida que usaron en años posteriores otros textos, sino que le brindaba al clero la posibilidad de difundir, mediante la oralidad, ${ }^{43}$ una mariología más ordenada acerca del culto al Quinche, ${ }^{44}$ y la capacidad de repotenciar el culto y convocar a los fieles.

\footnotetext{
${ }^{40}$ Georges Lomné, "La Revolución francesa y lo simbólico en la liturgia política bolivariana”, Miscelánea Histórica Ecuatoriana 2. 2 (1989): 41-67.

${ }^{41}$ Carlos Sono, Nuestra Señora del Quinche (Quito: Imprenta del Clero, 1883).

${ }^{42}$ Sono, Nuestra Señora 132.

${ }^{43}$ Carmen Fernández, "Siguiendo el camino del peregrino: como imaginar una geografía cristiana y moderna (1880-1910)", Escenarios para una patria: paisajismo ecuatoriano, 1850-1930, ed. Alexandra Kennedy-Troya (Quito: Museo de la Ciudad, 2008) 54-77.

${ }^{44}$ Esta obra se reeditaría en 1903 con unas cortas anexiones. Sin embargo, estas fueron cruciales ya que de manera indirecta planteaban el triunfo de la Virgen del Quinche sobre los liberales.
} 
Entre 1884 y 1885, por iniciativa de Carlos Sono y Abel García se mandó a elaborar con Joaquín Pinto, uno de los más afamados pintores de la Capital, algunos cuadros que representaban los milagros que la Virgen había efectuado durante la época colonial (Imagen 1). Dichos cuadros se colocaron en el santuario de la Virgen en el Quinche. También, Sono encargó a Joaquín Pinto un cuadro, en el que se retrataba a la imagen, para llevárselo consigo a la ciudad de Riobamba. ${ }^{45}$ De la misma década de 1880 datan otros cuadros producidos por artistas quiteños como Manuel Zambrano y Alejandro Salas.

Imagen 1. Joaquín Pinto, "Milagro de la Virgen del Quinche sobre un jinete que asistía a la construcción de su Santuario" (óleo sobre lienzo: 198 x 295 cm) 1885. Santuario de Quinche, Ecuador.

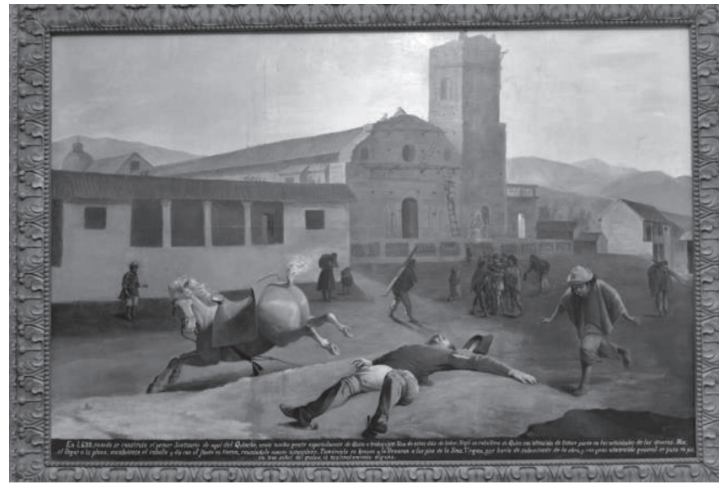

Fuente: fotografía de Roberto Salazar.

La obra de Sono se reeditó en 1903, ocho años después de que los liberales tomaron el poder. Las pocas añadiduras que tuvo esta segunda edición tuvieron como tema central los milagros de la Virgen durante la República, especialmente aquellos frente al liberalismo. Para no aludir directamente a los gobiernos de Eloy Alfaro o Leonidas Plaza (1901-1905; 1912-1916), Sono usó la imagen de uno de los primeros liberales de mediados del siglo XIX. No se trataba del registro de otro milagro, la escena que describía Sono apelaba a la capacidad que tenía la Virgen del Quinche para vencer al liberalismo a través de la conversión:

En la presidencia de Urbina, manifestó el pueblo del Quinche su aversión á la política liberal de tal Gobierno; lo cual inmutó al presidente y comisionó á un jefe correligionario para que viniera á tomar venganza del pueblo. [...] Pero Nuestra Señora del Quinche, que jamás desampara á sus hijos, libró á su pueblo de los desmanes, tropelías y atropellos que, á discreción, hubieran perpetrado el vengativo jefe y sus secuaces, entrando á hurtadillas por la noche.

Cuando bajaban la cuesta de Huaillabamba, se desató furibunda una tempestad eléctrica, pues los rayos se cernían por todos lados y muy cerca de ellos; una granizada glacial que los atería y arrebataba, donde los entumecidos negros veían inevitable la muerte que los circuía. Entonces el jefe desistiendo de las

\footnotetext{
${ }^{45}$ Carlos Sono era un sacerdote que pertenecía a la diócesis de Riobamba. Sin embargo, por años recibió permiso de sus superiores para trasladarse entre esa ciudad, Quito y el Quinche.
} 
vengativas prevenciones, y con acento compungido, invocó el auxilio de Nuestra Señora del Quinche ofreciéndola venir á celebrarle una fiesta y abstenerse de hacer mal alguno á los moradores del santuario. Como en efecto en ese momento cesó la tempestad, y quedó el cielo en apacible calma y serenidad; pudiendo entonces proseguir el camino ya sin peligro, y venir á prosternarse á los á los pies de la Santísima Virgen, y hacerle su romería. ${ }^{46}$

La historia de la Virgen y los relatos sobre ésta generaron una nueva memoria acerca del culto, plantearon un discurso sobre la Virgen, los enemigos de la Iglesia, las necesidades de ésta y el comportamiento de los fieles. Además, obras como la de Sono esbozaron la importancia del espacio en la práctica religiosa de los fieles. Este, para Carlos Sono, Juan Bautista Vaca y Carlos Acosta, párrocos del Quinche, no solo se limitaba a esa parroquia, sino también a Quito, las poblaciones aledañas y a Oyacachi, el cual fue incorporado jurisdiccionalmente al Quinche en 1902 con base en la religiosidad de los pobladores y la conexión histórica con que contaban ambas poblaciones. ${ }^{47}$

\subsection{Las Visitas}

A diferencia del segundo momento, que se abordará más adelante, entre 1883 y 1905, la Visitas de la Virgen del Quinche a Quito tuvieron especial prominencia. El principal motivo de estas fue movilizar las masas católicas de la Capital y de otras ciudades apelando a las características taumatúrgicas de la Virgen y a su identificación como remedio de males políticos. Este último se dio, principalmente, contra el liberalismo, o más bien, el clero incentivó las visitas frente a un contexto en el cual un gobierno o una reforma amenazaban la supremacía de la Iglesia. En otros casos, principalmente en las visitas de 1883 y 1895 , el objetivo principal era poner fin o evitar un cambio de gobierno.

La imagen de la Virgen representaba orden. Para el clero y la Iglesia, "[...] el instrumento de una dinámica argumental [...] acerca de la estructura de la sociedad, presentada como un código dado por Dios". ${ }^{48}$ La llegada de la Virgen, como remedio de males, significaba la restauración del orden social:

[La Iglesia,] hoy que sus enemigos procuran destruir sus templos y altares, la fe y piedad se hacen más poderosas para construirlos allí donde se quiere aniquilarlos: ¡Cuán suaves y eficaces son los frutos de la fe de nuestros pueblos! Bendito sea Dios que no permite destronar la Santa Fe Católica! Bendita la Gran Madre de Dios que nos la sostiene en medio de la persecución satánica!. ${ }^{9}$

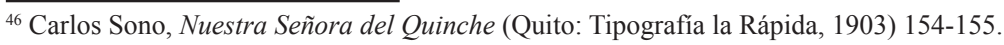

${ }^{47}$ Pedro Fernández y otros, "Pedido de los pobladores de Oyacachi para recibir sacramento" (Oyacachi, el 16 de diciembre de 1901), Caja 59, Archivo Arquidiocesano; Sono, Nuestra Señora del Quinche, 1883; Juan Bautista Vaca, "Sobre Oyacachi" (Quinche, el 15 de octubre de 1886), Parroquias, Archivo Arquidiocesano; Víctor María Carrillo, "Documentos del cura de Cangahua sobre Oyacachi" el 16 de enero de 1902, Caja 59, Archivo Arquidiocesano.

${ }^{48}$ Marina Warner, Tú sola entre las mujeres (Madrid: Taurus, 1991) 434.

${ }^{49}$ Alejandro López, “Crónica interior durante la Visita de 1905”, Boletín Eclesiástico 12 (1905): 612.
} 
El clero y los usos políticos de la Virgen del Quinche en la sierra centro-norte...

Como parte de las prácticas religiosas que el clero fomentó durante las visitas de la Virgen se encontraban procesiones ${ }^{50}$ rosarios,${ }^{51}$ triduos,${ }^{52}$ misas,${ }^{53}$ traslaciones ${ }^{54}$ para alentar a los fieles a defender la Religión y la Iglesia, ${ }^{55}$ mostrar el poder de convocatoria del clero, la fuerza de la Iglesia y la necesidad de proteger a la República. ${ }^{56}$ Esto implica que la Virgen no fue usada como una mera estrategia basada en ideas de protección como se lo hacía en la colonia o en la primera mitad del siglo XIX, sino que pasó a ser el mecanismo de movilización de las masas y de hacer público un rito, mostrando a "la Iglesia como mediadora entre los fieles y Dios". ${ }^{57}$ Entre 1883 y 1905 hubo siete visitas en la Sierra centro-norte (Tabla 1) que permitieron al clero poner en acción la reciente mariología sobre la Virgen del Quinche.

Tabla 1. Visitas de la Virgen del Quinche

\begin{tabular}{|c|c|c|c|}
\hline Año & Lugar & Motivo & Propiciado por \\
\hline $\begin{array}{c}1882- \\
1883\end{array}$ & Quito & Alentar el proyecto restaurador & $\begin{array}{c}\text { Arzobispo de Quito } \\
\text { Ignacio Ordóñez }\end{array}$ \\
\hline 1885 & Riobamba & $\begin{array}{c}\text { Fortalecer y fomentar el culto [Se } \\
\text { llevó un cuadro] }\end{array}$ & Carlos Sono \\
\hline $1887-$ \\
1888 & Quito & Jubileo de León XIII y contexto & $\begin{array}{c}\text { Julio María Matovelle, } \\
\text { Manuel María Pólit, } \\
\text { arzobispo de Quito } \\
\text { Ignacio Ordóñez }\end{array}$ \\
\hline 1889 & Ibarra & $\begin{array}{c}\text { Plaga de langostas [Disposición } \\
\text { de que el clero no participe en } \\
\text { elecciones] }\end{array}$ & $\begin{array}{c}\text { Obispo de Ibarra Pedro } \\
\text { Rafael González y } \\
\text { Calisto }\end{array}$ \\
\hline 1893 & Quito & Jubileo de León XIII & $\begin{array}{c}\text { Arzobispo de Quito } \\
\text { Ignacio Ordóñez } \\
\text { Arzobispo de } \\
\text { Quito Pedro Rafael } \\
\text { González y Calisto }\end{array}$ \\
\hline 1895 & Quito & Evitar el triunfo liberal & $\begin{array}{c}\text { Vicario Capitular de } \\
\text { Quito Ulpiano Pérez }\end{array}$ \\
\hline
\end{tabular}

Fuente: Elaboración propia. Ver notas de pie de la 50 a la 56.

\footnotetext{
${ }^{50}$ Aurelio Espinosa, "La Sma. Virgen del Quinche en Riobamba", República del Sagrado Corazón de Jesús, 1. 6 (1885): 412-415.

${ }^{51}$ Alejandro López, Visita de la Virgen del Quinche a Ibarra por pedido del Rafael González y Calisto (Quito: Imprenta Bolívar, 1889).

${ }^{52}$ Ulpiano Pérez, “Oficio al sacristán de la Catedral con motivo de la visita de la Virgen en 1905”, Quito, 25 de julio de 1905. Archivo Arquidiocesano de Quito, Quito, Secretaria de Gobierno, Caja 20.

53 “Crónica sobre misa a la Virgen del Quinche”, Diario de Quito, (Quito) 21 de marzo de 1895: 23.

54 “Sobre el traslado de la Virgen del Quinche de la Compañía a la Concepción”, El Pueblo, (Quito) 13 de julio 1895: 3 .

55 “Despedida del Batallón n. ${ }^{\circ} 4$ frente a la Virgen del Quinche”, El Pueblo, (Quito) 10 de agosto de 1895: 4.

${ }^{56}$ Ulpiano Pérez, "Exhortación sobre la Virgen del Quinche", Boletín Eclesiástico 12 (1905): 536-538.

${ }^{57}$ Sol Serrano, ¿Qué hacer con Dios en la República? (Santiago: Fondo de Cultura Económica, 2008) 260.
} 
De todas las visitas es preciso ahondar en las características de dos de ellas (1883 y 1895), y después hacer una aclaración sobre la Visita de 1905. En estas dos primeras, el clero trasladó a la Imagen con fines contrarrevolucionarios, mientras que, en la última, la curia asimiló la idea de que el liberalismo no dejaría el gobierno.

En 1882, el arzobispo de Quito, Ignacio Ordóñez, ordenó el traslado de la Virgen del Quinche con el fin de apaciguar los ánimos de numerosos sectores que se habían levantado contra el gobierno de Ignacio de Veintimilla. ${ }^{58}$ Poco después (1883), los grupos que se levantaron en armas en la Sierra lograron tomar la ciudad de Quito. El triunfo fue asociado con la presencia de la Virgen en la ciudad, dotándola de tintes antiliberales. Con el fin de obtener el control de la ciudad de Guayaquil, el gobierno provisional de Quito envió tropas y ofreció misas a la Virgen. A mediados de 1883 el puerto fue tomado y Veintimilla huyó de Ecuador. Ambos acontecimientos se adjudicaron a una intervención divina y la Virgen obtuvo fama de restauradora del orden. ${ }^{59}$ Una vez depuesto el gobierno liberal, los sectores que participaron en la guerra civil convocaron a una Asamblea Constituyente. El gobierno provisional y el clero negociaron la permanencia de la imagen en Quito hasta febrero de 1884 con el fin de apaciguar los ánimos y poder nombrar un nuevo Presidente Constitucional. ${ }^{60}$ De ese modo, el clero movilizó a sus masas por medio de la Virgen del Quinche en defensa de la unidad Estado-Iglesia.

En cambio, la visita de 1895 tomó un matiz diferente a la primera. La Virgen fue trasladada a Quito no para ayudar a la restauración, sino en apoyo al gobierno, para que este pudiese mantenerse en el poder, por lo cual la Virgen debía incentivar a las masas a unirse a los ejércitos, apoyar económicamente al Ejecutivo y así evitar el ascenso del liberalismo. ${ }^{61}$ De ese modo, el clero buscó evitar los "males" y reformas que los liberales traerían consigo. ${ }^{62}$ Sin embargo, los grandes actos públicos no pudieron evitar la derrota del gobierno, lo cual implicó una pugna sobre el significado antiliberal que tenía la Virgen del Quinche:

[Alfaro] El día ocho, pidió a la Virgen Santísima del Quinche para que la coloquen en un altar portátil a fin de que en el se celebre el Sacrificio y asistan sus tropas en la plaza, por no alcanzar la Iglesia: mas no fue conveniente esto pues los ignorantes atribuyan la victoria de los radicales y masones a nuestra Madre del Quinche, razón por la que, con orden del Ilustrísimo Señor Arzobispo Dr. D Pedro Rafael González y Calisto, fue colocada en el altar portátil Nuestra Señora de la Paz la portentosa imagen que llamamos la Patronita, por ser traída de España por las fundadoras de este Convento. Por la noche, se colocó la

\footnotetext{
${ }^{58}$ Ordóñez, "Circular a los venerables".

${ }^{59}$ Espinosa. "La Sma. Virgen"; Federico González Suárez "La Victoria del 9 de julio", El Monitor Eclesiástico 1. 4 (1883): 121-122.

${ }^{60}$ González Suárez, "Permanencia de la Imagen".

61 "Despedida del Batallón".

${ }^{62}$ José María Aguirre, "Plática del R. P. José María Aguirre, pronunciada en el templo de San Francisco el 30 de junio, con motivo de la procesión solemne salida de dicho templo", Boletín Eclesiástico 2 (1895): $302-$ 311; Pedro Rafael González y Calisto, "Carta Pastoral del Ilmo. arzobispo de Quito contra el Radicalismo", Boletín Eclesiástico 2 (1895): 281-289.
} 
El clero y los usos políticos de la Virgen del Quinche en la sierra centro-norte...

sagrada efigie de María Santísima del Quinche en una caja y se la llevaron en secreto a su Santuario por haber dispuesto así el Ilmo. Prelado; ¿Quién podría expresar el dolor que nos causó ver a nuestra amantísima Madre, retirarse como fugitiva, siendo la primera ocasión que regresaba a su templo dejando a su favorecida Quito en un mar de amargura? ${ }^{63}$

En cambio, a diferencia de las otras visitas, la de 1905 no tenía como objetivo derrocar ni respaldar un gobierno, más bien fue parte las primeras propuestas concretas de la Iglesia de un cambio acerca de su rol frente al Estado. Si bien la idea de una Iglesia independiente es decimonónica, en estos años, en Ecuador, lo que se evaluó fue la inconveniencia de la unión que ataba la Iglesia al Estado y que se demostraba por medio de los intentos de los liberales radicales por colocarla bajo el control de los poderes civiles. ${ }^{64}$ Es decir, en su discurso la Iglesia planteaba su independencia y libertad asegurando que había vivido diez años de persecución desde 1895:

[El clero] esperamos la solución á los puntos de diezmos. Confirmo más y más que parece llegado el caso de dar pruebas de independencia en la vida de la Iglesia; pues esta sujeción de hecho al querer del gobierno nos ha esclavizado más y más. Lo de los bienes y la supresión de monasterios tiene al público muy exasperado. ${ }^{65}$

Motivo de sobrenatural aliento es para Nos ver cómo la generalidad de los católicos no desmaya en acudir á Dios cuando las calamidades amenazan de cerca. El gran movimiento piadoso que se ha despertado en la Capital por ocasión de la Visita de la Santísima Virgen del Quinche está elocuentemente demostrando la sincera religiosidad de nuestra sociedad, y crece de punto esta manifestación cuando el clamor de todos en primer término es, pedir por intercesión de la Patrona poderosísima nos libre de la impiedad, cese la persecución, abra los ojos a los incrédulos, ponga en mejores vías á los gobernantes, se restituya la libertad á la Iglesia. ${ }^{66}$

Las visitas no fueron las únicas formas con las cuales el clero logró llevar a la práctica la mariología planteada por Sono. Las romerías al Quinche fueron cruciales en ese sentido. En estos años, si bien la peregrinación del 21 de noviembre, día de la fiesta de la Virgen, era importante, el clero buscó incentivar otras romerías a principios y fines de año en la década de 1880 para fomentar esta práctica católica en circunstancias políticas.

\footnotetext{
${ }^{63}$ Cf. Conceptas, "Libro de acontecimientos", El perfil de las mujeres conventuales, Sylvia Benítez (Quito: Instituto Metropolitano de Patrimonio, 2014) 195.

${ }^{64}$ Leonidas Plaza, Mensaje del presidente Leonidas Plaza al Congreso 1903 (Quito: Imprenta Nacional, 1903); Leonidas Plaza, Mensaje del presidente Leonidas Plaza al Congreso 1904 (Quito: Imprenta Nacional, 1904); Leonidas Plaza, Mensaje del presidente Leonidas Plaza al Congreso 1905 (Quito: Imprenta Nacional, 1905); Miguel Valverde, La clausura religiosa de la mujer (Quito: Tipografía de la Escuela de Artes y Oficios, 1904); “Acta de Sesión”, Quito, 22 de agosto de 1902. Archivo-Biblioteca de la Asamblea Nacional, Quito, Archivo General

${ }^{65}$ Pérez, "Carta del Vicario Capitular al Delegado Apostólico".

${ }^{66}$ Ulpiano Pérez, Circular sobre la visita de la Virgen del Quinche (Quito: Imprenta del Clero, 1905).
} 


\subsection{Las Romerías}

Estas prácticas, si bien coloniales, también se insertaron en el proceso de resignificación del culto a la Virgen del Quinche al marco republicano. Esto no quiere decir que la herencia colonial se suprimió por completo de las romerías. De hecho, éstas cambiaron de significados y características y se insertaron en iniciativas transnacionales basadas en las grandes peregrinaciones europeas. Clark explica que a diferencia de las peregrinaciones de siglos pasados que parecían ser anárquicas e indisciplinadas, las del siglo XIX se mostraron ordenadas y supervisadas por sacerdotes. ${ }^{67}$ Gran parte de esas características se evidenciaron en las romerías de los años 1886, 1887 y 1888 hacia el santuario del Quinche para recibir la eucaristía. En todas, el vicario general, Juan de Dios Campuzano, algunos prelados de las órdenes regulares y los jóvenes sacerdotes de la Juventud Católica encabezaron y organizaron lo que ellos denominaron: "[el inicio de] la era de las peregrinaciones, que tanto han contribuido á despertar y mantener vivos el celo y la fe católica en Europa". ${ }^{68}$

En las crónicas de la revista República del Sagrado Corazón de Jesús, estas romerías fueron descritas como el camino hacia un axis mundi, una "travesía de expiación", a modo de acto político en el cual participaban una serie de ciudadanos que a su vez eran fieles. Por un lado, asistieron hombres públicos y, también, jóvenes clérigos como Manuel María Pólit y Julio María Matovelle: ${ }^{69}$ "después de una patética exhortación del Sr. Vicario algunos Señores leyeron en alta voz sendas oraciones, en las que solicitaban la protección de Nuestra Señora del Quinche a favor de la Iglesia, de la República, del gobierno del Clero, de los padres de familia, de los artesanos, de los jóvenes y de los niños". ${ }^{70}$

Estas romerías, sumadas a las peregrinaciones anuales para la fiesta de la Virgen, dejaron ver algunas necesidades que tenía el culto frente a su número creciente de devotos, las cuales fueron resultas en distintos momentos por el mismo clero arquidiocesano. La primera de estas fue un manual que diera pautas acerca de cómo se debía participar en las romerías. Así, un primer intento se dio en 1887 cuando se aprobó el índice de un manual. ${ }^{71}$ Pero no sería hasta 1902 que se contó con El Romero del Quinche del jesuita Juan Bautista Vásquez. ${ }^{72}$ Por otro lado, el creciente número de fieles obligó a que la Arquidiócesis evaluase, entre 1902 y 1904, la necesidad de construir un nuevo santuario. ${ }^{73}$

\footnotetext{
${ }^{67}$ Clark, "The New Catholicism" 11-46.

${ }^{68}$ Manuel María Pólit, "Romería al Quinche”, República del Sagrado Corazón de Jesús 2.16 (1886): 455.

${ }^{69}$ Manuel María Pólit, "Romería al Quinche”, República del Sagrado Corazón de Jesús 2.28 (1887): 56-58.

${ }^{70}$ Pólit, "Romería al Quinche" 58.

${ }^{71}$ M. Pólit Cevallos, "Devocionario de la romería al Quinche", Quito, 8 de enero de 1887. Archivo Arquidiocesano de Quito, Quito, Parroquias, El Quinche, Caja 59.

${ }^{72}$ Ricardo Vázquez, Romero del Quinche (Pifo: La Concepción, 1904).

${ }^{73}$ Jacinto Pankeri, "Informe de Jacinto Pankeri sobre el estado del Santuario del Quinche e Informe de la reunión en la que el arzobispo deseaba coronar a la Virgen", Quito, 15 de marzo de 1902. Archivo Arquidiocesano de Quito, Quito, Nueva Serie, Caja 87.
} 
La prensa católica tuvo un papel importante en el seguimiento de las romerías, visitas, peregrinaciones y otros actos. Ésta no solo alimentaba la idea de un culto que unía a los fieles con aquellos que los precedieron, sino que también generaba, a partir de su circulación, la posibilidad de establecer una conexión imaginada ${ }^{74}$ entre quienes producían y leían las crónicas sobre la Virgen (el clero) y los que las recibían (los fieles).

\subsection{La Prensa}

El último tercio del siglo XIX fue importante para el fortalecimiento de la prensa, en especial de la prensa católica. Las revistas editadas por el clero, por lo general, incluían crónicas, asuntos administrativos de las diócesis, cartas pastorales, disposiciones y documentos pontificios. En el caso de la Virgen del Quinche y los usos que el clero hizo de la misma, se puede decir que la prensa católica no solo recogió la crónica sobre las prácticas religiosas, sino que la hizo central entre los asuntos que interesaban a la Iglesia. ${ }^{75}$

De ese modo, el clero le dio un lugar en la trama al culto a la Virgen del Quinche, lo que permitió su difusión a lo largo del territorio. Los párrocos tuvieron un papel central tanto como suscriptores de la República del Sagrado Corazón de Jesús, la Corona de María -de los dominicos- y el Boletín Eclesiástico ${ }^{76} \mathrm{y}$, a la par como difusores de las crónicas y asuntos de interés eclesiástico. ${ }^{77}$

La prensa, a la cual es necesario sumar las columnas de El Pueblo y El Industrial, de administración laica, propagaba por medio de crónicas la idea de un culto creciente, fuerte y eficaz. También fortalecían la idea de que aquellos fieles devotos a la Virgen del Quinche tenían la mejor prueba de su portentosa acción debido al gran historial de milagros que se exponía en Nuestra Señora del Quinche y al sentimiento de tener un fils (hilo) que los unía a otros devotos de épocas anteriores: ${ }^{78}$ "Siempre el pueblo de Quito se ha distinguido por su amor y culto á la Madre de Dios, en la ocasión presente ha querido unir á su veneración un testimonio evidentísimo de cuan vanos son todos los esfuerzos de la impiedad para arrancar de su corazón la fe, herencia grandiosa que recibiera de sus mayores". ${ }^{79}$ Durante este primer momento se documentaron las prácticas religiosas y victorias de la Virgen en Quito y su santuario, mostrando

\footnotetext{
${ }^{74}$ Benedict Anderson, Comunidades imaginadas. Reflexiones sobre el origen y la difusión del Nacionalismo (México: Fondo de Cultura Económica, 2011).

${ }^{75}$ Para el manejo de prensa, discurso y cultura política, véase: Galaxis Borja, “'Sois libres, sois iguales, sois hermanos' Sociedades democráticas en Quito de mediados del siglo XIX”, Jahrbuch für Geschichte Lateinamerikas-Anuario de Historia de América Latina 53 (2016): 185-210.

${ }^{76}$ El primero de estos periódicos era dirigido por Manuel María Matovelle y editado por Manuel María Pólit, ambos miembros de la Juventud Católica. Mientras que el último era el órgano oficial de la Iglesia en la Provincia Ecuatoriana y fue dirigido entre 1893 y 1905 por los canónigos Alejandro Mateus y Ulpiano Pérez. En cambio la Corona de María era un periódico dirigido por los padres dominicanos.

${ }^{77}$ La conexión entre los sacerdotes y los fieles a través de las noticias que los primeros llevaban se puede ver en el documento: Carlos Salvador, "Carta de Carlos Salvador sobre el avance liberal", 9 de agosto de 1895. Archivo Arquidiocesano de Quito, Quito, Parroquias, El Quinche, Caja 59.

${ }^{78}$ Danièle Hervieu-Léger, La religión, hilo de memoria (Barcelona: Herder, 2005).

${ }^{79}$ Padres Dominicanos, “Sobre la Visita de la Virgen del Quinche a Quito”, Corona de María 6 (1905): 197.
} 
el poder de la Iglesia frente al gobierno y al liberalismo: "Los 60 ó 70 pupos que depusieron sus armas en el Quinche, dijeron que sólo lo hacían porque dejaban sus armas á la Virgen Santísima ¡Gloria á la victoriosa!” ${ }^{80}$

A lo largo de casi tres décadas (1883-1905) el estudio de caso de los usos de la imagen de la Virgen del Quinche permite apreciar el posicionamiento de la Iglesia, y principalmente del clero, en defensa de una unión que le daba cierto control frente al Estado. También es posible entender el proceso de reconexión que buscaba tener el clero con los laicos como parte de una política pontificia de recristianización del mundo, lo que se puede apreciar en el impulso de los actos masivos de fe, el crecimiento del culto y la resignificación de este. Las prácticas que incentivó el clero dieron un giro después de 1905.

\section{El ordenamiento de las prácticas religiosas alrededor de la Virgen del Quinche y la construcción de una fortaleza espiritual (1906-1914)}

Después de las reformas aprobadas por los liberales, la promulgación de la Constitución de 1906 y la crisis de facciones del liberalismo, la Iglesia buscó su independencia frente al Estado. Durante esos mismos años, los usos de la imagen de la Virgen del Quinche también cambiaron. Los actores a cargo de esto fueron el arzobispo González Suárez y los párrocos del Quinche Carlos Acosta y Félix Granja.

El año de 1906 fue crucial debido a que la Arquidiócesis de Quito contó con un nuevo prelado después de tener su sede vacante por dos años. ${ }^{81}$ Federico González Suárez dio inicio a un proceso en el cual logró de Roma la provisión de obispos residentes para la gran mayoría de diócesis y con ello dio paso a lo él decía: "“...] yo y todos mis Ilmos. y Rmos. Sufragáneos estamos creando de nuevo las diócesis de esta Provincia eclesiástica ecuatoriana". ${ }^{82}$ Esta afirmación es crucial para entender el panorama en el que se desenvolvió la Iglesia, y principalmente el clero, después de 1906. Esto marcó la capacidad de negociar y concertar con el Poder Central por medio de sus nexos con

\footnotetext{
80 "Pupos deponen sus armas en el Quinche para la Virgen", El Pueblo, (Quito) 24 de julio de 1895: 4.

${ }^{81}$ Enrique Ayala Mora maneja la visión de que 1906 fue un año que dio paso a un cambio generacional en la jerarquía eclesiástica ecuatoriana. Véase: Ayala 336-366. Sin embargo, este es un análisis muy simple que no toma en cuenta el contexto paralelo de formación que tuvieron los prelados del siglo XX respecto a los que gobernaron las diócesis a fines del XIX. Lo cierto es que la Iglesia en Ecuador, a principios del siglo XX sufrió un fuerte proceso de acefalía debido a las muertes de sus obispos. Hasta 1905, las diócesis de Loja, Manabí, Cuenca, Riobamba y Quito se encontraban vacantes y el único obispo residente en Ecuador era el de Ibarra, Federico González Suárez. Desde 1907, una vez este en la cátedra metropolitana se designaron obispos para todas las diócesis. Estos manejaron sus respectivas diócesis de manera diferente y más negociadora que sus predecesores, pero no debido a un mero cambio generacional, sino a que las circunstancias de la Iglesia después de 1906 eran distintas. De hecho, muchos de estos jóvenes clérigos fueron formados y asimilaron la formación religiosa romanizada impulsada por el garcianismo y habían participado junto a sus predecesores en procesos como el de la Restauración, la defensa del proyecto garciano a fines del siglo XIX o la oposición al liberalismo a fines del siglo XIX.

${ }^{82}$ González Suárez, "Carta de Federico González Suárez a Andrés Machado”, 468.
} 
la sociedad civil, organizada en asociaciones de laicos llamadas Acciones Católicas, ${ }^{83}$ y a las que se les entregó un papel más activo dentro de la Iglesia, ${ }^{84}$ por medio del fortalecimiento de sus vínculos con el clero, principalmente en espacios que le eran propios y otros que eran de su administración.

El caso de la Virgen del Quinche va a permitir explicar, en este segundo momento, la construcción de estos espacios que le eran exclusivamente propios a la Iglesia. Para esto, el clero usó la imagen de la Virgen del Quinche dentro del proyecto de independencia frente al Estado a través la revalorización y ordenamiento de su culto, peregrinaciones, resignificación de las visitas y la construcción de un nuevo santuario.

\subsection{Revalorización y ordenamiento del culto}

Una vez agotadas las posibilidades de negarse a aceptar el cargo de arzobispo, ${ }^{85} \mathrm{Federico}$ González Suárez programó su viaje desde Ibarra hacia Quito. El recibimiento de los fieles, la colocación del pabellón nacional y el pontificio, y el repique de campanas fueron los únicos actos que la curia pidió que se cumplieran. Más allá de la ostensión, su interés yacía en la religiosidad. ${ }^{86}$ González Suárez acogió las políticas de León XIII de no intervención en política, ${ }^{87}$ el estricto cumplimiento de las disposiciones del Concilio Plenario Latinoamericano ${ }^{88}$ y la idea de prácticas religiosas ordenadas, modernas y experienciales como sucedía en Europa ${ }^{89}$ Aquello, sumado al contexto de una Iglesia que buscaba su independencia, lo llevó a enfatizar dicho programa para la religiosidad y tomar en cuenta para eso a uno de los cultos más importantes en la arquidiócesis, fortalecido durante 30 años. Eventualmente, junto a los párrocos del Quinche intentó armar una especie de fortaleza espiritual. Esto fue una muestra de la clara intención del clero de participar en una esfera pública en la que se pudiesen

\footnotetext{
${ }^{83}$ Gioconda Herrera, "The Catholic Church and Public life under liberalism" (Tesis, Doctorado, University of Columbia, 2006).

${ }^{84}$ Federico González Suárez, "Quinta Instrucción Pastoral sobre la evangelización de los indios", Obras Pastorales del Ilmo. Sr. D. Federico González Suárez, vol. 2, ed. Manuel María Pólit (Quito: Imprenta del Clero, 1928) 312-331.

${ }^{85}$ Con la muerte de Pedro Rafael González y Calisto, el clero ecuatoriano, al igual que el papado, estuvieron preocupados de que la diócesis más importante de Ecuador quedase acéfala. Por lo cual, la Santa Sede escogió a Federico González Suárez, hasta entonces obispo de Ibarra, para que ocupase ese cargo. Entre 1905 y 1906, González Suárez se negó a aceptar la designación, ante lo cual interpuso una serie de pedidos para que se eligiera a otra persona. Sin embargo, Pío X rechazó todos sus pedidos y ordenó que fuera proveído como arzobispo.

${ }^{86}$ Ulpiano Pérez, Invitación sobre la entrada de Federico González Suárez a Quito (Quito: Imprenta del Clero, 1906).

${ }^{87}$ Federico González Suárez, "Primera Instrucción Pastoral sobre la participación del clero en política", Obras Pastorales del Ilmo. Sr. D. Federico González Suárez, vol. 2, ed. Manuel María Pólit (Quito: Imprenta del Clero, 1928) 192-253.

${ }^{88}$ Obispos de América Latina, Actas y decretos del Concilio Plenario de la América Latina (Roma: Tipografía Vaticana, 1906).

${ }^{89}$ Federico González Suárez, "Segunda Instrucción Pastoral sobre los abusos en la celebración de las fiestas religiosas", Obras Pastorales del Ilmo. Sr. D. Federico González Suárez, vol. 2, ed. Manuel María Pólit (Quito: Imprenta del Clero, 1928) 254-268.
} 
desenvolver sin perder el control social con el que contaba, lo cual requería ejercer presión sobre el Estado sin que este pudiese inmiscuirse en asuntos eclesiales. Sin duda, también fue parte de la "reconstrucción" de la Provincia ecuatoriana que refería González Suárez.

En ese contexto, el nuevo arzobispo, en su camino a Quito, decidió detenerse en el Quinche, postrarse frente a la imagen de la Virgen y poner la arquidiócesis bajo su cuidado. ${ }^{90}$ Este acto inauguraba simbólicamente su idea sobre el manejo de la religiosidad en el Quinche. El clero ya no llevaría la Imagen a Quito. Por el contrario, se alentaría a que los fieles caminen al Quinche para rendirle culto a la Virgen. Así, una pedagogía de la distancia era capaz de alentar la fe de quienes asistían..$^{91}$ De ese modo, el Quinche se colocaba como el culto más importante de la región. Además, era uno de los pocos cultos de gran convocatoria que era administrado directamente por el clero secular y las autoridades arquidiocesanas.

Al tener un culto tan importante como el Quinche, a la curia se le hizo necesario controlarlo más de cerca. De ese modo, en 1910, González Suárez intentó establecer disposiciones reglamentarias que chocaban con las prácticas y la religiosidad popular durante las romerías. ${ }^{92}$ Sin embargo, esto generó la preocupación del párroco Félix Granja, quien advirtió que el culto se vería afectado. ${ }^{93}$ Después de una negociación con el vicario Arsenio Suárez, se modificó el reglamento matizando el interés del arzobispo de regular las prácticas, pero sin perjudicar el culto.

\subsection{Las peregrinaciones}

En este segundo momento, las peregrinaciones tomaron protagonismo frente a las visitas. Los símbolos alrededor de la peregrinación tenían la connotación de reconocer la subordinación de los fieles a la Virgen, lo que, a su vez, implicaba el fortalecimiento de las relaciones entre el clero y la sociedad civil en los temas referentes a la diacronía propia del culto. En esa relación tomó fuerza el camino penitencial y el esfuerzo de peregrinar en un contexto en el que el discurso del clero acusaba una persecución; frente a ésta, la Virgen representaba un consuelo. ${ }^{94}$

Es preciso referir brevemente las visitas ya que, si bien se procuró evitarlas, éstas se volvieron eventuales y al ser un acto ya no tan usual, adquiría gran trascendencia

\footnotetext{
${ }^{90}$ Ulpiano Pérez, "Viaje de Federico González Suárez", Quito, 10 de abril de 1906. Archivo Arquidiocesano de Quito, Quito, Secretaría de Gobierno, Caja 16.

${ }^{91}$ Fernández-Salvador, "Siguiendo el camino".

${ }^{92}$ Federico González Suárez, "Proyecto de un plan de reglamento para las romerías al Santuario de Nuestra Señora del Quinche", Chaupicruz, 26 de agosto de 1910. Archivo Arquidiocesano de Quito, Quito, Parroquias, El Quinche, Caja 58.

${ }^{93}$ Félix Granja, "Comentarios del párroco sobre el reglamento de la romería del Quinche”, Quito, 12 de septiembre de 1910. Archivo Arquidiocesano de Quito, Parroquias, El Quinche, Caja 58.

${ }_{94}$ Alejandro López, "Crónica Interior sobre peregrinación de la Virgen del Quinche 1908”, Boletín Eclesiástico 15 (1908): 902-903; Alejandro López, "Crónica Interior sobre la Peregrinación al Quinche", Boletín Eclesiástico 17 (1910): 877.
} 
religiosa. En 1910, el arzobispo estuvo a punto de ordenar el traslado de la Imagen del Quinche con motivo del conflicto armado con Perú. Pero no fue hasta 1914 que González Suárez cedió y envió por la imagen. Al quedar las visitas en último plano, la necesidad de acelerar la construcción del santuario se volvió imperiosa por una doble razón. Por un lado, el número de fieles que asistía al Quinche crecía cada año. ${ }^{95}$ Mientras que, por el otro, la Iglesia, con los grandes proyectos arquitectónicos del siglo XX, mostraban su poder económico y su imagen "renovada" ${ }^{96}$

Si bien la construcción arrancó en 1904, el rápido impulso que tuvo hasta su conclusión, en 1925, se dio a partir de los cambios en la administración de González Suárez. La arquitectura no solo se presentaba como complementaria a la peregrinación, sino que mostraba el poder de la Iglesia frente al Estado. En este caso económico, pues el clero calculaba los costos de la obra en 200000 sucres. ${ }^{97}$ Si bien estos fueron cubiertos de manera indirecta por los fieles que asistían al santuario o daban limosnas para la obra, el clero manejó el discurso de que la Virgen "protegía la construcción de su santuario y lo financió ella". ${ }^{98}$ Así, la Iglesia mostraba que podía sostenerse por sí misma, apuntalando el discurso sobre su autonomía.

La idea de que el Quinche se perfiló como una fortaleza espiritual debido al programa en el que se deseaba insertarlo, la atención que se le puso, el crecimiento de su culto, la construcción de un nuevo santuario para alojarlo y su característica de ser un espacio únicamente controlado por la Iglesia fueron parte del estandarte de la Iglesia sobre su independencia.

\section{Conclusiones}

Este artículo, en su inicio, hizo hincapié en analizar los usos políticos de la Virgen del Quinche entre 1883 y 1914. Estos usos estuvieron ligados al interés del clero por lograr el apoyo de los fieles y así movilizarlos en apoyo de su posicionamiento religioso y político, ya sea en las ciudades (1883-1905) o hacia el santuario mariano (1906-1914). Es preciso notar que dicho culto fue parte del proceso en el cual el clero pasó de una postura intransigente en la cual defendía una República católica y la unión Estado-Iglesia, a otro que buscaba su independencia.

Las reformas emprendidas por los liberales y los ajustes que debió hacer el clero frente a la crisis que afrontó su jerarquía hacia 1905, llevaron a la Iglesia, y principalmente al clero, a replantear su postura, pues la unión de entidades ya no parecía convenirle. Así, entre 1905 y 1907 se dieron los primeros pasos, desde los sectores eclesiásticos en

\footnotetext{
${ }^{95}$ Alejandro López. "Crónica Interior sobre" 877.

${ }^{96}$ Alexandra Kennedy-Troya, Élites y la Nación en obras (Cuenca: Universidad de Cuenca, Casa de la Cultura Núcleo Azuay, 2016).

${ }^{97}$ Félix Granja, "Pedido de Félix Granja ante el posible traslado de la Virgen en 1905”, Quito, 1905. Archivo Arquidiocesano de Quito, Quito, Parroquias, El Quinche, Caja 58.

${ }^{98}$ Ulpiano Pérez y otros, “Autos sobre un prodigio”, Quito, 1906. Archivo Arquidiocesano de Quito, Quito, Parroquias, El Quinche, Caja 59, Archivo Arquidiocesano; Pankeri, “Informe de Jacinto Pankeri”.
} 
búsqueda de la independencia de la Iglesia. El estudio se ha enfocado en la región sierra centro-norte de Ecuador, pues ésta concentraba el mayor porcentaje de miembros del clero, esto implicaba que muchos de estos participaron y apoyaron las prácticas que se llevaron a cabo alrededor del culto a la Virgen del Quinche. Sin embargo, se rescata la participación de obispos como Ignacio Ordóñez, Pedro Rafael González y Calisto y Federico González Suárez; canónigos como Ulpiano Pérez, Alejandro López, Juan de Dios Campuzano y Carlos Sono; jóvenes presbíteros con participación política como Julio María Matovelle o Manuel María Pólit; y párrocos del Quinche como Carlos Acosta o Juan Bautista Vaca.

En un primer momento, una mariología local como discurso oficial articuló las prácticas que se incentivaron alrededor de la Virgen del Quinche con miras de movilizar a las masas tanto en romerías como en visitas de la Virgen a Quito y otras ciudades de notable importancia. Las prácticas por un lado procuraron fortalecer las relaciones entre los miembros de la Iglesia y convencer a los devotos de una postura antiliberal alimentada por una intransigencia religiosa que se resistía a separar la Iglesia del Estado. Entre 1883 y 1895, el combate del clero contra el liberalismo vinculó la imagen de la Virgen del Quinche con la deposición de presidentes liberales o la esperanza de que ese grupo no llegase a tomar el gobierno. Llegados los gobiernos liberales, entre 1895 y 1905, la defensa acérrima de la unión de ambas entidades decayó paulatinamente para dar paso a la queja sobre los intentos del poder civil de controlar a la Iglesia.

En el segundo momento, el contexto social y político era diferente. La idea de independizarse del Estado no solo se volvió más concreta con la vigencia de la Constitución de 1906, sino que también fortaleció la convicción del clero acerca de la necesidad de apegarse al programa de recristianizar el mundo y reforzar espacios eclesiales en los que el Poder Central no podía intervenir. Para eso, era necesario brindarle un mayor protagonismo a la sociedad civil una vez que se diese paso a un programa que reformó la religiosidad. Esto conformaría un cuerpo de laicos más devotos, que se pudo ver, principalmente, en el fortalecimiento de las peregrinaciones hacia el Quinche y en la demostración del poderío económico de la Iglesia. Ésta demostraba que era capaz de conservar su participación en el espacio público y su control social sin necesidad de controlar directamente al Estado. La construcción del culto a la Virgen del Quinche como parte de una fortaleza espiritual también estuvo ligado al conflicto de jurisdicciones que el clero rivalizaba con el gobierno liberal, como en el conflicto por la provisión de obispos en 1907. El clero no quiso ceder más espacios a las instituciones seculares, por el contrario, buscó fortalecer las que aún controlaba.

Los usos políticos de la Virgen del Quinche no se detuvieron en 1914. La Iglesia, años después, identificó más enemigos en Ecuador. Conforme avanzó el siglo XX, el liberalismo se volvió uno de tantos. El socialismo y el comunismo hicieron que el clero buscara nuevas estrategias. Así, la Virgen del Quinche y su santuario continuaron insertos en la religiosidad al igual que en política. 
El clero y los usos politicos de la Virgen del Quinche en la sierra centro-norte...

\section{Bibliografía}

\section{Fuentes primarias}

\section{Archivo}

Archivo Arquidiocesano de Quito, Quito, Parroquias, El Quinche.

Archivo Arquidiocesano de Quito, Quito, Secretaría de Gobierno.

Archivo Arquidiocesano de Quito, Quito, Nueva Serie.

Archivo Nacional del Ecuador, Quito, Ministerio del Interior, Pichincha.

Archivo-Biblioteca de la Asamblea Nacional, Quito, Archivo General.

\section{Prensa}

Diario de Quito (Quito) 1895.

El Comercio (Quito) 1909.

El Industrial (Quito) 1893.

El Pueblo (Quito) 1895.

\section{Artículos de revistas}

Aguirre, José María. "Plática del R. P. José María Aguirre, pronunciada en el templo de San Francisco el 30 de junio, con motivo de la procesión solemne salida de dicho templo". Boletín Eclesiástico 2 (1895): 302-311.

Espinosa, Aurelio. "La Sma. Virgen del Quinche en Riobamba". República del Sagrado Corazón de Jesús 1.6 (1885): 412-415.

González Suárez, Federico. "La Victoria del 9 de julio”. El Monitor Eclesiástico 1.4 (1883): 121-122.

González y Calisto, Pedro Rafael. "Carta Pastoral del Ilmo. arzobispo de Quito contra el Radicalismo”. Boletín Eclesiástico 2 (1895): 281-289.

López, Alejandro. "Crónica interior durante la Visita de 1905". Boletín Eclesiástico 12 (1905): 611-612. 
López, Alejandro. "Crónica Interior sobre la peregrinación al Quinche”. Boletín Eclesiástico 17 (1910): 877.

López, Alejandro. "Crónica Interior sobre peregrinación de la Virgen del Quinche 1908”. Boletín Eclesiástico 15 (1908): 902-903.

Matovelle, Julio María. "Nuestro Propósito”. República del Sagrado Corazón de Jesús 1.1 (1884): 1-6.

Padres Dominicanos. "Sobre la Visita de la Virgen del Quinche a Quito". Corona de María 6 (1905): 197.

Pérez, Ulpiano. "Exhortación sobre la Virgen del Quinche". Boletín Eclesiástico 12 (1905): 536-538.

Pólit, Manuel María. “Nuestra Señora del Quinche”. República del Sagrado Corazón de Jesús 5.43 (1888): 270.

Pólit, Manuel María. "Romería al Quinche”. República del Sagrado Corazón de Jesús 2.16 (1886): 453-458.

Pólit, Manuel María. "Romería al Quinche". República del Sagrado Corazón de Jesús 2.28 (1887): 56-58.

Pólit, Manuel María. “Traslación de la Santísima Virgen del Quinche”. República del Sagrado Corazón de Jesús 5.40 (1888).

\section{Impresos}

González Suárez, Federico. "Primera Instrucción Pastoral sobre la participación del clero en política”. Obras Pastorales del Ilmo. Sr. D. Federico González Suárez, vol. 2. Ed. Manuel María Pólit. Quito: Imprenta del Clero, 1928.

González Suárez, Federico. "Quinta Instrucción Pastoral sobre la evangelización de los indios”. Obras Pastorales del Ilmo. Sr. D. Federico González Suárez, vol. 2. Ed. Manuel María Pólit. Quito: Imprenta del Clero, 1928.

González Suárez, Federico. "Segunda Instrucción Pastoral sobre los abusos en la celebración de las fiestas religiosas". Obras Pastorales del Ilmo. Sr. D. Federico González Suárez, vol. 2. Ed. Manuel María Pólit. Quito: Imprenta del Clero, 1928.

López, Alejandro. Visita de la Virgen del Quinche a Ibarra por pedido del Rafael González y Calisto. Quito: Imprenta Bolívar, 1889.

Obispos de América Latina. Actas y decretos del Concilio Plenario de la América Latina. Roma: Tipografía Vaticana, 1906. 
El clero y los usos politicos de la Virgen del Quinche en la sierra centro-norte...

Ordóñez, Ignacio. Circular a los venerables párrocos de la Arquidiócesis. Quito: Imprenta del Clero, 1883.

Pérez, Ulpiano. Circular sobre la visita de la Virgen del Quinche. Quito: Imprenta del Clero, 1905.

Pérez, Ulpiano. Invitación sobre la entrada de Federico González Suárez. Quito: Imprenta del Clero, 1906.

Plaza, Leonidas. Mensaje del presidente Leonidas Plaza al Congreso 1903. Quito: Imprenta Nacional, 1903.

Plaza, Leonidas. Mensaje del presidente Leonidas Plaza al Congreso 1905. Quito: Imprenta Nacional, 1905.

Puga, Amalio. La ley y el Ilmo. Federico González Suárez. Quito: Imprenta Nacional, 1908.

Sono, Carlos. Nuestra Señora del Quinche. Quito: Imprenta del Clero, 1883.

Sono, Carlos. Nuestra Señora del Quinche. Quito: Tipografía la Rápida, 1903.

Valverde, Miguel. La clausura religiosa de la mujer. Quito: Tipografía de la Escuela de Artes y Oficios, 1904.

Vázquez, Ricardo. Romero del Quinche. Pifo: La Concepción, 1904.

\section{Fuentes secundarias}

\section{Libros}

Anderson, Benedict. Comunidades imaginadas. Reflexiones sobre el origen y la difusión del Nacionalismo. México: Fondo de Cultura Económica, 2011.

Ayala, Enrique. Historia de la revolución liberal ecuatoriana. Quito: Corporación Editora Nacional, 2002.

Brading, David. Virgen de Guadalupe. México: Taurus, 2002.

Burdick, Michael. For God and the Fatherland. Religion and politics in Argentina. New York: The State University of New York press, 1995.

Buriano, Ana. Navegando en la borrasca. Construir la nación de la fe en el mundo de la impiedad, Ecuador, 1860-1875. México: Instituto Mora, 2008. 
Castillo, Santiago. La Iglesia y la Revolución Liberal. Quito: Banco Central del Ecuador, 1995.

Ceballos Ramírez, Manuel. El catolicismo social: un tercero en discordia. México: Colegio de México, 1991.

Connaugton, Brian. Entre la voz de Dios y el llamado de la patria. México: Fondo de Cultura Económica, Universidad Autónoma Metropolitana, 2010.

Hervieu-Léger, Danièle. La religión, hilo de memoria. Barcelona: Herder, 2005.

Hidalgo, Fernando. La República del Sagrado Corazón. Quito: Corporación Editora Nacional, UASB, 2013.

Kennedy-Troya, Alexandra. Élites y la Nación en obras. Cuenca: Universidad de Cuenca, Casa de la Cultura Núcleo Azuay, 2016.

Moreno, José Alberto. Devociones políticas: cultura católica y politización en la Arquidiócesis de México, 1880-1920. México: Colegio de México, 2013.

Orquera Polanco, Katerinne. La agenda educativa en el periodo liberal-radical 18951912. Quito: Universidad Andina Simón Bolívar, 2015.

Ramón, Francisco. La Virgen del Pilar dice... Usos Politicos y nacionales de un culto mariano. Zaragoza: Universidad de Zaragoza, 2014.

Robalino Dávila, Luis. Orígenes del Ecuador hoy. El ocaso del Viejo luchador, t. 8. Puebla: Cajica, 1969.

Serrano, Sol. ¿Qué hacer con Dios en la República? Santiago: Fondo de Cultura Económica, 2008.

Warner, Marina. Tú sola entre las mujeres. Madrid: Taurus, 1991.

\section{Capítulos de libros}

Bautista, Adriana. "La coronación pontificia de las imágenes marianas de México y la afirmación en la soberanía social de la Iglesia católica durante el porfiriato". Diálogos con una trayectoria intelectual: Marcelo Carmagnani en El Colegio de México. Ed. Yovana Celaya. México: Colegio de México, 2014.

Clark, Christopher. "The New Catholicism and the European culture wars". The European culture war. Eds. Christopher Clark y Wolfram Kaiser. New York: Cambridge University press, 2003. 
El clero y los usos politicos de la Virgen del Quinche en la sierra centro-norte...

Conceptas. "Libro de acontecimientos". El perfil de las mujeres conventuales, Sylvia Benítez. Quito: Instituto Metropolitano de Patrimonio, 2014.

Fernández, Carmen. "Siguiendo el camino del peregrino: como imaginar una geografía cristiana y moderna (1880-1910)". Escenarios para una patria: paisajismo ecuatoriano, 1850-1930. Ed. Alexandra Kennedy-Troya. Quito: Museo de la Ciudad, 2008.

Fogelman, Patricia. "Dos exvotos contra el Estado liberal: la Basílica y el libro de Salvaire sobre la historia del culto de Luján”. El culto mariano en Luján y San Nicolás. Eds. Patricia Fogelman, Mariela Ceva y Claudia Touris. Buenos Aires: Biblos, 2013.

Goetschel, Ana María. "Las paradojas del liberalismo y las mujeres: coyuntura 19071909”. Celebraciones centenarias y negociaciones por la nación ecuatoriana. Ed. Valeria Coronel y Mercedes Prieto. Quito: FLACSO, 2010.

Maiguashca, Juan. "El proceso de integración nacional en el Ecuador: el rol del poder central, 1830-1895". Historia y Región en el Ecuador. Ed. Juan Maiguashca. Quito: FLACSO, York University, IFEA, 1994.

Sinardet, Emmanuelle. "El papel de los padres de familia: táctica de la Iglesia en la Lucha contra las reformas educativas liberales en Ecuador (1906-1914)". Familia y educación en Iberoamérica. Coord. Pilar Gonzalbo. México: Colegio de México, 1999.

\section{Artículos de revistas}

Anderson, Margaret. "Las huestes papales: el resurgimiento católico y la transición europea hacia la democracia". Historia y Sociedad 6 (1999): 38-67.

Bidegain, Ana María. "De la historia eclesiástica la historia de las religiones". Historia critica 12 (1996): 5-16.

Blancarte, Roberto. "Laicidad y laicismo en América Latina”. Estudios Sociológicos 26 (2008): 139-164.

Borja, Galaxis. “'Sois libres, sois iguales, sois hermanos' Sociedades democráticas en Quito de mediados del siglo XIX". Jahrbuch für Geschichte Lateinamerikas-Anuario de Historia de América Latina 53 (2016): 185-210.

Langlois, Claude. "Conférence de M. Claude Langlois". Écloe practique des hautes études, section des sciences religieuses. Annuaire 140 (1995): 481-490.

Lomné, Georges. "La Revolución francesa y lo simbólico en la liturgia política bolivariana". Miscelánea Histórica Ecuatoriana 2. 2 (1989): 41-67. 
Stefano, Roberto Di. “¿De qué hablamos cuando decimos 'Iglesia’? Reflexiones sobre el uso historiográfico de un término polisémico". Ariadna histórica. Lenguajes, conceptos, metáforas 1 (2012): 197-220.

\section{Tesis, ponencias, documentos y otros Inéditos}

Herrera, Gioconda. "The Catholic Church and Public life under liberalism". Tesis de Doctorado, University of Columbia, 2006.

Stefano, Roberto Di. "Catolicismo, secularización y laicidad en América Latina”. Ponencia en Religión y Política en América Latina, Quito, FLACSO, 2015. 